\title{
Author Correction: Jacalin capped platinum nanoparticles confer persistent immunity against multiple Aeromonas infection in zebrafish
}

\author{
Khan Behlol Ayaz Ahmed ${ }^{1}$, Thiagarajan Raman ${ }^{1,2}$ \& Anbazhagan Veerappan $\mathbb{D}^{1}$ \\ Correction to: Scientific Reports https://doi.org/10.1038/s41598-018-20627-3, published online 02 February 2018 \\ The original version of this Article contained a typographical error in the spelling of the author Anbazhagan \\ Veerappan, which was incorrectly given as Anbazhgan Veerappan. This has now been corrected in the PDF and \\ HTML versions of the Article, and in the accompanying Supplementary Information file.
}

(c) (i) Open Access This article is licensed under a Creative Commons Attribution 4.0 International cc. License, which permits use, sharing, adaptation, distribution and reproduction in any medium or format, as long as you give appropriate credit to the original author(s) and the source, provide a link to the Creative Commons license, and indicate if changes were made. The images or other third party material in this article are included in the article's Creative Commons license, unless indicated otherwise in a credit line to the material. If material is not included in the article's Creative Commons license and your intended use is not permitted by statutory regulation or exceeds the permitted use, you will need to obtain permission directly from the copyright holder. To view a copy of this license, visit http://creativecommons.org/licenses/by/4.0/.

(C) The Author(s) 2018

${ }^{1}$ School of Chemical and Biotechnology, SASTRA University, Thirumalaisamudram, Thanjavur, 613401, Tamil Nadu, India. ${ }^{2}$ Department of Advanced Zoology and Biotechnology, Ramakrishna Mission Vivekananda College, Mylapore, Chennai, 600004, India. Correspondence and requests for materials should be addressed to T.R. (email: thiagi2007@ gmail.com) or A.V. (email: anbazhagan@scbt.sastra.edu) 